\title{
Evaluation of the Antidiarrheal Activity of Hydromethanol Crude Extracts of Ruta chalepensis and Vernonia amygdalina in Mice
}

\author{
Amsalu Degu (iD, ${ }^{1}$ Belayneh Kefale, ${ }^{2}$ Diriba Alemayehu $\left(\mathbb{D},{ }^{3}\right.$ \\ and Gobezie Temesgen Tegegne ${ }^{4}$ \\ ${ }^{1}$ School of Pharmacy and Health Sciences, United States International University-Africa, Nairobi, Kenya \\ ${ }^{2}$ Department of Pharmacy, College of Health Sciences, Debre Tabor University, Debre Tabor, Ethiopia \\ ${ }^{3}$ Department of Pharmacy, College of Medicine and Health Sciences, Ambo University, Ambo, Ethiopia \\ ${ }^{4}$ Department of Pharmacology and Clinical Pharmacy, School of Pharmacy, College of Health Sciences, Addis Ababa University, \\ Addis Ababa, Ethiopia \\ Correspondence should be addressed to Amsalu Degu; amsaludegu@yahoo.com
}

Received 14 November 2019; Revised 25 February 2020; Accepted 20 March 2020; Published 13 April 2020

Academic Editor: Nunziatina De Tommasi

Copyright (C) 2020 Amsalu Degu et al. This is an open access article distributed under the Creative Commons Attribution License, which permits unrestricted use, distribution, and reproduction in any medium, provided the original work is properly cited.

\begin{abstract}
Background. The herbal medicine practitioners in Ethiopia have used a wide range of medicinal plants as antidiarrheal agents. Among these, Ruta chalepensis and Vernonia amygdalina were claimed to have antidiarrheal activity in Ethiopian folklore medicine. Hence, the aim of the present study was to evaluate the antidiarrheal activity of the crude extracts of Ruta chalepensis and Vernonia amygdalina in mice. Methods. The crude extracts were obtained by cold maceration with $80 \%$ methanol, and its antidiarrheal activities were evaluated using a castor oil-induced diarrheal model. The test groups were treated with 100, 200, and $400 \mathrm{mg} / \mathrm{kg}$ body weight (bw) of the crude extract of each plant, while the positive controls and negative controls were given loperamide (3 mg/kg.bw) and 2\% Tween $80(10 \mathrm{ml} / \mathrm{kg} . \mathrm{bw})$, respectively. Results. In the castor oil-induced model, the crude extract of Ruta chalepensis (200 and $400 \mathrm{mg} / \mathrm{kg} . \mathrm{bw}$ ) significantly prolonged the onset of diarrhea in mice. Besides, it also showed a significant reduction in the frequency of stooling and weight of feces. Contrastingly, the crude extract of Vernonia amygdalina had a significant effect in delaying the onset of time of diarrhea and reduction of the frequency of stool and the weight of feces only at the maximum tested dose $(400 \mathrm{mg} / \mathrm{kg} . \mathrm{bw})$. Conclusion. The present study demonstrated that the crude leaves extract of Ruta chalepensis (200 and $400 \mathrm{mg} / \mathrm{kg} . \mathrm{bw})$ and Vernonia amygdalina (400 mg/kg.bw) possessed significant antidiarrheal activity in the castor oil-induced diarrheal model.
\end{abstract}

\section{Background}

Despite the advancement of medicine, diarrheal diseases are still the second leading cause of death among children under the age of five. [1] Globally, herbal medicines account for $80 \%$ of the healthcare needs of the majority of developing countries. [2] Even though the drug manufacturing industry has developed a large number of drugs, indigenous phytotherapy is still practiced in several rural areas, using treatments handed down from generation to generation. [3] In Ethiopia, about $80 \%$ of populations relied on traditional medicine due to the cultural acceptability, relatively low cost of traditional medicine, and limited access to modern health facilities. [4].

Despite advances of science in the understanding of the causes, treatment, and prevention of diarrheal diseases, significant number of children's death occur every year. $[5,6]$ Even if sufficient drugs are available for treating diarrhea, the majority of the existing drugs suffer from adverse effects like the induction of bronchospasm, vomiting (racecadotril), intestinal obstruction, constipation (loperamide) [7], and dependency (diphenoxylate). [8] Because of this, there is a necessity of strengthening research into medicinal plants to investigate alternative drugs from natural products. [9]. 
Furthermore, the use of medicinal plants for the treatment of diarrhea in folk medicine is a routine practice in many countries of the world. However, in most of the cases, these practices were handed down from generation to generation empirically without knowing the plausible mechanisms, safety, and efficacy of herbal treatments. [10] Among these plants, the leaves extract of Vernonia amygdalina and Ruta chalepensis has a claimed folklore use as an antidiarrheal agent. $[11,12]$ Besides, the previous study by Olayemi et al. showed that the ethanolic stem bark extract of Vernonia amygdalina had significant antidiarrheal activity. [13] Besides, the methanolic aerial parts extract of Ruta chalepensis had significant antisecretory activity on cholera toxin-induced intestinal secretion in a rat jejunal loops model. [14] Despite this traditional claim and previous studies, it was not fully investigated scientifically to validate its therapeutic effect. Hence, the present study aimed to scientifically validate its importance to corroborate the traditional claim in Ethiopia.

\section{Methods}

2.1. Drugs and Chemicals. Castor oil (Amman Pharmaceutical Industries), loperamide (Daehwa Pharmaceuticals), distilled water, Tween 80 (Atlas Chemical Industries Inc.), and methanol (Fisher Scientific, UK) were used in the study.

2.2. Plant Material. Fresh leaves of Ruta chalepensis and Vernonia amygdalina were collected from the Gondar and Gedo districts in October 2018. A taxonomist (Professor Sebsebe Demissew) authenticated the plant, and a voucher specimen (number AD002 and AD002) was deposited at the National Herbarium of Addis Ababa University for future reference. The collected leaves were cleaned using tap water to remove dust particles. Later on, the leaves were dried under shade at room temperature and then rumpled to a coarse powder using a mortar and pestle.

2.3. Experimental Animals. Swiss albino mice of either sex with a weight of 20-30 g and age of 6-8 weeks were used for the experiment. The animals were sourced from the animal house of the Department of Pharmacy, Ambo University. The animals were kept in the medium plastic cages (measures $28 \mathrm{~cm}$ length, $17 \mathrm{~cm}$ width, and $15.5 \mathrm{~cm}$ height) at room temperature with a $12 \mathrm{~h}$ light-dark cycle, relative humidity of $30 \%$, and free access to pellet food and water ad libitum. Before the experiment, the animals were acclimatized to the laboratory condition for one week. [14] All the experiments for this study were done following the guideline for the care and use of laboratory animals [15].

2.4. Preparation of the Crude Extract. Three hundred grams of powdered plant material of each plant was macerated in an Erlenmeyer flask with $80 \%$ methanol for a period of $72 \mathrm{~h}$ with occasional shaking using an orbital shaker. It was then filtered two times with Whatman filter paper (NO.1). To increase the percentage yield of the extract, the residue was remacerated two times for a total of 6 days. Then, methanol was removed from the filtrate using a rotary evaporator. Finally, the filtrate was placed in an oven to remove water. After drying and removal of methanol, the percentage yield of the semisolid crude leaves extracts of Ruta chalepensis and Vernonia amygdalina was found to be $26.7 \%$ and $23.3 \%$, respectively.

2.5. Grouping and Dosing. The mice were randomly allocated into five groups of six animals per group. The first group was assigned as a negative control and administered $2 \%$ Tween 80 at a dose of $10 \mathrm{ml} / \mathrm{kg}$.bw. The second group was assigned as a positive control and administered with standard drug loperamide at a dose of $3 \mathrm{mg} / \mathrm{kg}$.bw. The rest of the groups were treated with 100, 200, and $400 \mathrm{mg} / \mathrm{kg}$.bw of the crude extract. Effective dose selection was based on an oral acute toxicity study of the crude extract as well as pilot experiments. Since there were no observed signs and symptoms of toxicity at $2000 \mathrm{mg} / \mathrm{kg}$.bw, $1 / 20^{\text {th }}, 1 / 10^{\mathrm{th}}$, and $1 /$ $5^{\text {th }}$ of $2000 \mathrm{mg} / \mathrm{kg}$.bw doses were used for the actual experiment. The extract was reconstituted with $2 \%$ of Tween 80 during the day of the experiment and administered orally.

\section{Determination of Antidiarrheal Activity}

3.1. Castor Oil-Induced Diarrhea. In order to determine the antidiarrheal activity of the medicinal plants, the method described by Umer et al. [15] was employed for this study. Swiss albino mice of either sex were deprived of food with free access to water for $18 \mathrm{~h}$. Then, the mice were randomly allocated and treated with their respective doses. One hour later, all the mice were given $0.5 \mathrm{ml}$ of castor oil orally with oral gavage. Then, the mice were separately placed in cages with the floor lined with transparent paper and changed every hour. The mice were carefully followed for $4 \mathrm{~h}$ to measure the time of onset of diarrhea, frequency of defecation, and weight of feces excreted by the animals. The antidiarrheal activity of each crude extract was reported with the percentage of fecal output and diarrheal inhibition as described in the following formula $[16,17]$ :

$$
\% \text { of inhibition }=\frac{\text { average number of } \mathrm{WFC}-\text { average number of WFT }}{\text { average number of WFC }} * 100 \text {, }
$$


where $\mathrm{WFC}=$ average number of wet feces in the control group and WFT =average number of wet feces in the test group, and

$$
\begin{aligned}
\text { percentage of fecal output }= & \frac{\text { mean fecal weight of each group }}{\text { mean fecal weight of control }} \\
& * 100 .
\end{aligned}
$$

3.2. Preliminary Phytochemical Screening. The qualitative phytochemical investigations of the hydromethanol crude extracts of Ruta chalepensis and Vernonia amygdalina leaves were carried out using standard tests as described as follows. [18].

3.2.1. Test for Terpenoids (Salkowski Test). To $0.5 \mathrm{~g}$ of each of the crude extract leaves, $2 \mathrm{ml}$ of chloroform was added. Then, $3 \mathrm{ml}$ concentrated sulfuric acid was carefully added to form a layer. A reddish brown coloration of the interface indicates the presence of terpenoids.

3.2.2. Test for Saponins. To $0.5 \mathrm{~g}$ of each of the crude extract leaves, $5 \mathrm{ml}$ of distilled water was added in a test tube. Then, the solution was shaken vigorously and observed for a stable persistent froth. Formation of froth indicates the presence of saponins.

3.2.3. Test for Tannins. About $0.5 \mathrm{~g}$ of each of the crude extract leaves was boiled in $10 \mathrm{ml}$ of water in a test tube and then filtered. A few drops of $0.1 \%$ ferric chloride were added. A brownish green or a blue-black precipitate indicated the presence of tannins.

3.2.4. Test for Flavonoids. About $10 \mathrm{ml}$ of ethyl acetate was added to $0.2 \mathrm{~g}$ of each of the crude extract leaves and heated on a water bath for $3 \mathrm{~min}$. The mixture was cooled and filtered. Then, about $4 \mathrm{ml}$ of the filtrate was taken and shaken with $1 \mathrm{ml}$ of dilute ammonia solution. The layers were allowed to separate, and the yellow color in the ammoniacal layer indicated the presence of flavonoids.

3.2.5. Test for Cardiac Glycosides (Keller-Killiani Test). To $0.5 \mathrm{~g}$ of each of the crude extract leaves diluted to $5 \mathrm{ml}$ in water was added $2 \mathrm{ml}$ of glacial acetic acid containing one drop of ferric chloride solution. This was underlayed with $1 \mathrm{ml}$ of concentrated sulfuric acid. A brown ring at the interface indicated the presence of a deoxysugar characteristic of cardenolides. A violet ring may appear below the brown ring, while in the acetic acid layer a greenish ring may form just above the brown ring and gradually spread throughout this layer.

3.2.6. Test for Steroids. Two $\mathrm{ml}$ of acetic anhydride was added to $0.5 \mathrm{~g}$ each of the crude extract leaves of each sample with $2 \mathrm{ml}$ sulfuric acid. The color changed from violet to blue or green in some samples indicating the presence of steroids.

3.2.7. Test for Alkaloids. $0.5 \mathrm{~g}$ of the extract was diluted to $10 \mathrm{ml}$ with acid alcohol, boiled, and filtered. To $5 \mathrm{ml}$ of the filtrate, $2 \mathrm{ml}$ of dilute ammonia and $5 \mathrm{ml}$ of chloroform were added and shaken gently to extract the alkaloidal base. The chloroform layer was extracted with $10 \mathrm{ml}$ of acetic acid. This was divided into two portions. Mayer's reagent was added to one portion and Dragendorff's reagent to the other. The formation of a cream (with Mayer's reagent) or a reddish brown precipitate (with Dragendorff's reagent) was regarded as positive for the presence of alkaloids.

3.3. Statistical Analysis. The data were entered and analyzed using the Statistical Package for the Social Sciences (SPSS) version 21.0 software. One-way analysis of variance (ANOVA) followed by Tukey's post hoc test was employed to analyze the difference between group means. The result was expressed as mean \pm standard error of the mean (SEM), and $P<0.05$ was considered as statistically significant.

3.4. Ethical Approval. Ethical clearance was obtained from the Ethical Review Board of Ambo University, College of Medicine and Health Sciences, Department of Pharmacy (protocol number: Phar/12/2017). After the experiment, the animals were ethically sacrificed with the use of sodium pentobarbital euthanasia.

\section{Results}

4.1. Effects on Castor Oil-Induced Diarrhea in Mice. In the castor oil-induced diarrheal model, the crude leaves extract of Ruta chalepensis leaves significantly prolonged the time of diarrheal onset and the frequency of stooling at $200 \mathrm{mg} /$ kg.bw and $400 \mathrm{mg} / \mathrm{kg}$.bw tested doses. Besides, the present study revealed that the percentage of diarrheal inhibition compared to controls was $23.6 \%(P<0.05)$ and $51.31 \%$ $(P<0.05)$ at the doses of 200 and $400 \mathrm{mg} / \mathrm{kg} . b w$, respectively. In addition, at the maximum tested doses $(400 \mathrm{mg} /$ kg.bw), the crude extract of Ruta chalepensis produced almost comparable effect (51.31\%) with loperamide (62.8\%). Nonetheless, at the dose of $100 \mathrm{mg} / \mathrm{kg} . \mathrm{bw}$, the extract did not have significant antidiarrheal effect in this model (Table 1).

The crude leaves extract of Vernonia amygdalina significantly prolonged the onset of diarrheal feces and decreased the frequency of wet feces defection only at the doses of $400 \mathrm{mg} / \mathrm{kg} . \mathrm{bw}$. This fraction produced the highest percentage of diarrheal inhibition (55.01\%) at $400 \mathrm{mg} / \mathrm{kg} . b w$, which was comparable with that of the standard drug (62.8 $\%$ ). Contrastingly, the $100 \mathrm{mg} / \mathrm{kg} . \mathrm{bw}$ and $200 \mathrm{mg} / \mathrm{kg} . \mathrm{bw}$ tested doses of the extract did not possess significant antidiarrheal activity as compared to the negative control (Table 2).

As depicted in Table 1, there was a dose-dependent reduction in the percentage of mean fecal output among all tested doses of the crude extract Ruta chalepensis with 
TABLE 1: Effect of the crude extract of Ruta chalepensis leaves on castor oil-induced diarrheal model in mice.

\begin{tabular}{|c|c|c|c|c|c|}
\hline Group & $\begin{array}{l}\text { Onset time of diarrhea } \\
(\mathrm{min})\end{array}$ & $\begin{array}{c}\text { Total \# of wet feces in } \\
4 \mathrm{~h}\end{array}$ & $\begin{array}{c}\text { Total weight of feces } \\
\text { (gm) }\end{array}$ & $\begin{array}{l}\text { \% Inhibition of } \\
\text { defecation }\end{array}$ & $\begin{array}{c}\text { \% Mean fecal } \\
\text { output }\end{array}$ \\
\hline Control & $87.33 \pm 29.96$ & $2.67 \pm 0.67$ & $1.85 \pm 0.24$ & - & - \\
\hline $\begin{array}{l}\text { Loperamide } \\
3 \mathrm{mg} / \mathrm{kg}\end{array}$ & $234.3 \pm 3.81^{*}$ & $1 \pm 0.52^{*}$ & $0.55 \pm 0.18^{*}$ & 62.8 & 30 \\
\hline $\mathrm{CE} 100 \mathrm{mg} / \mathrm{kg}$ & $82.8 \pm 25$ & $2.3 \pm 0.62$ & $1.03 \pm 0.25$ & 13.86 & 56 \\
\hline $\mathrm{CE} 200 \mathrm{mg} / \mathrm{kg}$ & $93.5 \pm 40^{*}$ & $3.3 \pm 0.84^{*}$ & $0.98 \pm 0.24^{*}$ & 23.6 & 53 \\
\hline $\mathrm{CE} 400 \mathrm{mg} / \mathrm{kg}$ & $206.3 \pm 31.53^{*}$ & $1.3 \pm 0.67^{*}$ & $0.63 \pm 0.11^{*}$ & 51.31 & 34 \\
\hline
\end{tabular}

Note. Values are expressed as mean $\pm \operatorname{SEM}(n=6)$, and analysis was performed with one-way ANOVA followed by the Tukey test, ${ }^{*} P<0.05$. CE $=$ crude extract, and controls received $10 \mathrm{ml} / \mathrm{kg}$ of $2 \%$ Tween 80 in distilled water. SEM: standard error of the mean and ANOVA: analysis of variance.

TABle 2: Effect of the crude extract of Vernonia amygdalina leaves on castor oil-induced diarrheal model in mice.

\begin{tabular}{lccccc}
\hline Group & $\begin{array}{c}\text { Onset time of diarrhea } \\
(\mathrm{min})\end{array}$ & $\begin{array}{c}\text { Total \# of wet feces in } \\
4 \mathrm{~h}\end{array}$ & $\begin{array}{c}\text { Total weight of feces } \\
\text { (gm) }\end{array}$ & $\begin{array}{c}\text { \% Inhibition of } \\
\text { defecation }\end{array}$ & $\begin{array}{c}\text { \% Mean fecal } \\
\text { output }\end{array}$ \\
\hline Control & $87.33 \pm 29.96$ & $2.67 \pm 0.67$ & $1.85 \pm 0.24$ & - & - \\
Loperamide & $234.3 \pm 3.81^{*}$ & $1 \pm 0.52^{*}$ & $0.55 \pm 0.18^{*}$ & 62.8 & 30 \\
$3 \mathrm{mg} / \mathrm{kg}$ & $40.8 \pm 28.3$ & $2.5 \pm 0.8$ & $1.2 \pm 0.25$ & 6.4 & 65 \\
$100 \mathrm{mg} / \mathrm{kg}$ & $128 \pm 44.7$ & $2.3 \pm 0.49$ & $0.9 \pm 0.31$ & 13.85 & 59 \\
$200 \mathrm{mg} / \mathrm{kg}$ & $156.8 \pm 38^{*}$ & $1.2 \pm 0.8^{*}$ & $0.58 \pm 0.12^{*}$ & 55.01 \\
$400 \mathrm{mg} / \mathrm{kg}$ & & &
\end{tabular}

Note. Values are expressed as mean $\pm \operatorname{SEM}(n=6)$, and analysis was performed with one-way ANOVA followed by the Tukey test, ${ }^{*} P<0.05 ; \mathrm{CE}=\mathrm{crude}$ extract, and controls received $10 \mathrm{ml} / \mathrm{kg}$ of $2 \%$ Tween 80 in distilled water. SEM: standard error of the mean and ANOVA: analysis of variance.

$400 \mathrm{mg} / \mathrm{kg} . \mathrm{bw}$ tested dose showing the highest effect (34\%). Similarly, the crude leaves extract Vernonia amygdalina showed the maximum effect (31\%) at the highest tested doses ( $400 \mathrm{mg} / \mathrm{kg} . \mathrm{bw})$ to lessen the percentage of mean fecal output (Table 2).

4.2. Preliminary Phytochemical Screening. Phytochemical screening test revealed that alkaloids, tannins, and saponins were detected in both crude extracts. However, flavonoids, cardiac glycosides, terpenoids, and steroids were exclusively found in crude leaves extracts of Ruta chalepensis (Table 3).

\section{Discussion}

Castor oil is the most commonly used diarrhea inducer in mice models. [19] Ricinoleic acid, the active metabolites of castor oil, is responsible for the diarrhea-inducing properties of castor oil. [20].

In the castor oil-induced diarrheal model, the crude leaves extract of Ruta chalepensis significantly prolonged the diarrheal onset and the frequency of stooling at middle and higher tested doses. This study is in line with other study which showed the hydromethanolic crude extract of Indigofera spicata at 200 and $400 \mathrm{mg} / \mathrm{kg}$.bw doses had statistically significant inhibition of the frequency of defecation. [21] The significant antidiarrheal activity of this plant could be due to the probable localization of secondary metabolites to inhibit castor oil-induced fluid secretion. Besides, the crude leaves extract of Ruta chalepensis (200 and $400 \mathrm{mg}$ / kg.bw) showed a significant percentage of diarrheal inhibition as compared to the controls which can further corroborate its antidiarrheal potential to undergo further investigation. Surprisingly, at the maximum tested doses
(400 mg/kg.bw), the crude extract of Ruta chalepensis showed almost comparable effect with the standard drug. This dose-dependent effect of the crude extract may be probably due to the augmentation of the therapeutic concentration of the secondary metabolites as a result of increased dose. Nonetheless, at the dose of $100 \mathrm{mg} / \mathrm{kg} . \mathrm{bw}$, the extract was devoid of significant antidiarrheal effect in this model. Phytochemical screening study showed that the leaves extract of Ruta chalepensis was endowed with alkaloids, flavonoids, polyphenols, terpenoids, cardiac glycosides, and saponins. [22] Previous studies showed that terpenoids and steroids like phytosterols have a capacity to inhibit the production of prostaglandin E2 [23, 24], which has a crucial role in the stimulation of intestinal secretions. $[25,26]$ Accordingly, the significant antidiarrheal activity observed in the Ruta chalepensis crude extract at different doses could probably be linked to the presence of these secondary metabolites in the crude extract. Besides, Moazedi et al. [27] reported that the hydroalcoholic leaves extract of Ruta chalepensis had a significant antispasmodic effect on rat ileum. This could probably suggest its antidiarrheal effect by inhibition of castor oil-induced gastrointestinal motility.

The crude leaves extract of Vernonia amygdalina had shown significant antidiarrheal activity by extending the onset of diarrhea and reducing the frequency of defection only at a maximum tested dose ( $400 \mathrm{mg} / \mathrm{kg}$.bw). This could probably suggest the low potency of this medicinal plant as compared to the Ruta chalepensis leaves extract. Contrastingly, the lower and middles doses of the extract did not have significant antidiarrheal activity on castor oil-induced diarrhea as compared to the negative control, which could be probably due to low concentration of bioactive metabolites at lower and middle tested doses. 
TABle 3: Preliminary phytochemical screening of hydromethanol crude extracts of Ruta chalepensis and Vernonia amygdalina leaves.

\begin{tabular}{lcc}
\hline $\begin{array}{l}\text { Secondary } \\
\text { metabolites }\end{array}$ & $\begin{array}{c}\text { Ruta chalepensis } \\
\text { crude extract }\end{array}$ & $\begin{array}{c}\text { Vernonia amygdalina } \\
\text { crude extract }\end{array}$ \\
\hline Alkaloids & + & + \\
Tannins & + & + \\
Saponins & + & + \\
Terpenoids & + & - \\
Steroids & + & - \\
Flavonoids & + & - \\
Anthraquinones & - & - \\
Cardiac glycosides & + & - \\
\hline
\end{tabular}

$+=$ present and $-=$ absent.

The present study showed that maximum reduction in the percentage of the mean fecal output was achieved at the maximum tested dose $(400 \mathrm{mg} / \mathrm{kg} . \mathrm{bw})$ in both extracts. This could suggest the probable localization of the active ingredients in the uppermost doses of the crude extracts of both medicinal plants.

Although the phytochemical constituents responsible for the antidiarrheal effect are yet to be identified, and the amount of phytochemical constituents that are responsible for impeding gastrointestinal motility such as tannins $[28,29]$ and alkaloids [7] appear to increase with dose. This could possibly be the reason why significant antidiarrheal effect was observed at the higher doses of the crude extracts of both medicinal plants. However, at the lower and middle doses of the crude leaves extract of Vernonia amygdalina, the significant antidiarrheal effect was not observed in this model. This might be due to the lack of secondary metabolites such as terpenoids [24], steroids [23], and flavonoids [30, 31] that could inhibit castor oil-induced fluid secretion in the intestine.

\section{Conclusion}

The present study demonstrated that the crude leaves extract of Ruta chalepensis (200 and $400 \mathrm{mg} / \mathrm{kg} . \mathrm{bw}$ ) and Vernonia amygdalina (400 mg/kg.bw) possessed significant antidiarrheal activity due to its inhibitory effect on castor oil-induced gastrointestinal fluid secretion. The antidiarrheal activities of these crude extracts could probably be attributed to the presence of bioactive agents in both medicinal plants.

\section{Data Availability}

The datasets used and/or analyzed during the current study will be obtained from the corresponding and the first author of this project.

\section{Conflicts of Interest}

The authors declare that they do not have any conflicts of interest.

\section{Acknowledgments}

First, the authors would like to thank Ambo University for the financial support of this project. Their sincere gratitude also goes to the Department of Pharmacy laboratory technicians for their consistent help in the laboratory activities and constant care of the laboratory animals. This study was supported by Ambo University.

\section{References}

[1] WHO, "Diarrhoeal disease," 2017, https://www.who.int/ news-room/fact-sheets/detail/diarrhoeal-disease.

[2] H. S. Kim, "Do not put too much value on conventional medicines," Journal of Ethnopharmacology, vol. 100, no. 1-2, pp. 37-39, 2005.

[3] A. H. Gilani and A. U. Rahman, "Trends in ethnopharmacology," Journal of Ethnopharmacology, vol. 100, no. 12, pp. 43-49, 2005.

[4] K. D. Kassaye, A. Amberbir, B. Getachew, and Y. Mussema, "A historical overview of traditional medicine practices and policy in Ethiopia," The Ethiopian Journal of Health Development, vol. 20, no. 2, pp. 127-134, 2006.

[5] M. Kosek, C. Bern, and R. L. Guerrant, "The global burden of diarrhoeal disease, as estimated from studies published between 1992 and 2000," Bulletin of the World Health Organization, vol. 81, no. 81, pp. 197-204, 2003.

[6] N. Thapar and I. R. Sanderson, "Diarrhoea in children: an interface between developing and developed countries," The Lancet, vol. 363, no. 9409, pp. 641-653, 2004.

[7] E. A. Palombo, "Phytochemicals from traditional medicinal plants used in the treatment of diarrhoea: modes of action and effects on intestinal function," Phytotherapy Research, vol. 20, no. 9, pp. 717-724, 2006.

[8] A. Mehra, S. Sarkar, and D. Basu, "Lomotil (diphenoxylate) dependence in India," Indian Journal of Psychological Medicine, vol. 35, no. 35, pp. 248-250, 2013.

[9] A. Mohammed, H. Ahmed, A. D. Goji, A. O. Okpanachi, I. Ezekiel, and Y. Tanko, "Preliminary anti-diarrhoeal activity of hydromethanolic extract of aerial part of Indigofera pulchrain Rodents," Asian Journal of Medical Sciences, vol. 1, no. 2, pp. 22-25, 2009.

[10] A. M. Mujumdar, A. V. Misar, M. V. Salaskar, and A. S. Upadhye, "Antidiarrhoeal effect of an isolated fraction (JC) of Jatropha curcas roots in mice," Journal of Natural Remedies, vol. 1, no. 2, pp. 89-93, 2001.

[11] T. H. Bekalo, S. D. Woodmatas, and Z. A. Woldemariam, "An ethnobotanical study of medicinal plants used by local people in the lowlands of Konta Special Woreda, southern nations, nationalities and peoples regional state, Ethiopia," Journal of Ethnobiology and Ethnomedicine, vol. 5, p. 26, 2009.

[12] F. Mesfin, S. Demissew, and T. Teklehaymanot, "An ethnobotanical study of medicinal plants in Wonago Woreda, SNNPR, Ethiopia," Journal of Ethnobiology and Ethnomedicine, vol. 5 , no. 1, p. 28, 2009.

[13] A. A. Olayemi, A. O. Temitope, and K. B. David, "Evaluation of antidiarrheal activity of the ethanolic stem bark extract of Vernonia amygdalina in experimental animals," Journal of Natural Sciences Research, vol. 6, no. 10, pp. 61-66, 2016.

[14] C. Velázquez, F. Calzada, J. Torres, F. González, and G. Ceballos, "Antisecretory activity of plants used to treat gastrointestinal disorders in Mexico," Journal of Ethnopharmacology, vol. 103, no. 1, pp. 66-70, 2006.

[15] National Research Council, Guide for the Care and Use of Laboratory Animals, The National Academies Press, Washington, DC, USA, 8th edition, 2011.

[16] S. Umer, A. Tekewe, and N. Kebede, "Antidiarrhoeal and antimicrobial activity of Calpurnia aurea leaf extract," BMC Complementary Medicine and Therapies, vol. 13, p. 21, 2013. 
[17] K. Dosso, B. B. Nguessan, A. P. Bidie et al., "Antidiarrhoeal activity of an ethanol extract of the stem bark of Piliostigma reticulatum (Caesalpiniaceae) in rats," African Journal of Traditional, Complementary and Alternative Medicines, vol. 9, no. 2, pp. 242-249, 2012.

[18] G. A. Ayoola, H. A. Coker, S. A. Adesegun et al., "Phytochemical screening and antioxidant activities of some selected medicinal Plants used for malaria therapy in Southwestern Nigeria," Tropical Journal of Pharmaceutical Research, vol. 7, no. 3, pp. 1019-1024, 2008.

[19] U. T. Mamza, O. A. Sodipo, I. Z. Khan, and B. Wampana, "Evaluation of antidiarrhoeal Activity of ethanolic extract from the leaves of Phyllanthus amarus (Euphorbiacea)," International Journal of Green and Herbal Chemistry, vol. 3, no. 1, pp. 171-178, 2014.

[20] A. Rahman, S. N. Hasan, K. S. Sampad, and A. K. Das, "Antinociceptive, anti diarrheoal and cytotoxic activities of Rhizophora mucronata Lamk," Pharmacologyonline, vol. 1, pp. 921-929, 2011.

[21] K. S. Komal and A. C. Rana, "Herbal apporaches for diarrhea: A review," International Research Journal of Pharmacy, vol. 4, no. 1, pp. 31-38, 2013.

[22] E. M. Birru, A. B. Asrie, G. M. Adinew, and A. Tsegaw, "Antidiarrheal activity of crude methanolic root extract of Idigofera spicata Forssk.(Fabaceae)," BMC Complement Altern Med, vol. 16, p. 272, 2016.

[23] D. A. Gelayee, M. Abdelwuhab, and A. B. Asrie, "In vivo antiplasmodial activity evaluation of the leaves of Ruta chalepensis L. (Rutaceae) against Plasmodium berghei," Discovery Phytomedicine, vol. 4, no. 1, pp. 1-7, 2017.

[24] A. B. Awad, J. Toczek, and C. S. Fink, "Phytosterols decrease prostaglandin release in cultured P388D1/MAB macrophages," Prostaglandins, Leukotrienes and Essential Fatty Acids, vol. 70, no. 6, pp. 511-520, 2004.

[25] M. A. Fernández, M. P. Tornos, M. D. García, B. De las Heras, A. M. Villar, and M. T. Sáenz, "Anti-inflammatory activity of abietic acid, a diterpene isolated fromPimenta racemosavar. grissea," Journal of Pharmacy and Pharmacology, vol. 53, no. 6, pp. 867-872, 2001.

[26] M. J. Bern, C. W. Sturbaum, S. S. Karayalcin, H. M. Berschneider, J. T. Wachsman, and D. W. Powell, "Immune system control of rat and rabbit colonic electrolyte transport. Role of prostaglandins and enteric nervous system," Journal of Clinical Investigation, vol. 83, no. 6, pp. 1810-1820, 1989.

[27] A. A. Moazedi, N. Dabir, M. K. G. Naseri, and M. R. Zadkarami, "Investigated antispasmodic effect of Ruta chalepensis leaf on Rat's ileum at present of $\mathrm{KCl}$ and different concentrations of calcium chloride," Journal of Biological Sciences, vol. 9, no. 2, pp. 159-164, 2009.

[28] C. E. Almeida, M. G. O. Karnikowski, R. Foleto, and B. Baldisserotto, "Analysis of antidiarrhoeic effect of plants used in popular medicine," Revista de Saúde Pública, vol. 29, no. 6, pp. 428-433, 1995.

[29] A. K. Yadav and V. Tangpu, "Antidiarrheal activity ofLithocarpus dealbata. andUrena lobata. Extracts: therapeutic implications," Pharmaceutical Biology, vol. 45, no. 3, pp. 223-229, 2007.

[30] M. Hämäläinen, R. Nieminen, M. Asmawi, P. Vuorela, H. Vapaatalo, and E. Moilanen, "Effects of flavonoids on prostaglandin E2Production and on COX-2 and mPGES-1 expressions in activated macrophages," Planta Medica, vol. 77, no. 13, pp. 1504-1511, 2011.
[31] F. Sánchez de Medina, J. Gálvez, M. González, A. Zarzuelo, and K. E. Barrett, "Effects of quercetin on epithelial chloride secretion,” Life Sciences, vol. 61, no. 61, pp. 2049-2055, 1997. 